\title{
A'augusta mãe por cima das ondas do oceano': a corte portuguesa no púlpito brasileiro
}

\author{
The 'august mother over the waves of the ocean': the Portuguese court \\ on Brazilian pulpit
}

\author{
Maria Renata da Cruz Duran ${ }^{1}$
}

\section{RESUMO}

A parenética lusitana ganhou força no período das grandes navegações, em que a atuação missionária se justificava em função tanto da criação de um horizonte comum, quanto no fortalecimento da coesão cultural promovida pela cristianização do mundo ocidental. Crônicas de viagem e parenética missionária se fundiram na geração de uma unidade discursiva lusófona ao longo do período moderno. Nas igrejas, aqueles que nem tinham contato com o mundo de letras, nem acesso às grandes naus, sacavam seus bilhetes de viagem dos sermões que ouviam com atenção. Não obstante, a idealização de novos territórios era partilhada por sermonistas que descreveram cidades inteiras sem nunca tê-las visto. Tal é o caso de algumas orações acerca de Portugal e Brasil, sobretudo no período em que a transferência da corte lusitana para a capital fluminense conformou uma aproximação mais efetiva entre essas duas partes do Império. Nomeado pregador régio por d. João VI, frei Francisco de São Carlos Ihe devotou a "Oração de Ação de Graças, recitada no dia $1^{\circ}$ de Marco de 1809 na Capela Real, dia de aniversário da feliz chegada de sua alteza real a esta cidade" a d. João VI. Nas palavras do frei uma Lisboa que se desvenda pelas memórias e presença de novas personagens na cena fluminense. Na oração, uma descrição do patrimônio imaterial que representava a sociabilidade da corte e sustentava a manutenção do Antigo Regime. Acerca do alargamento das fronteiras do conhecimento forjado no trânsito lusófono trata a presente apresentação, guiada pelas viagens imaginárias à que sermonistas e pregadores transportam a população desses dois lados do Quinto Império.

Palavras-chave: Oratória sagrada, expansão marítima, Império português, literatura brasileira.

1 Universidade Estadual de Londrina. Professora de História Moderna e Contemporânea na Universidade Estadual de Londrina, pós-doutoranda na Faculdade de Letras da Universidade de Lisboa, sob a supervisão da professora Isabel Drumond Braga, bolsista PDE/CNPq 2017-2018. CV completo em: http://lattes.cnpq.br/6065557882134228. E-mail: mariarenataduran@gmail.com. 


\section{ABSTRACT}

The lusophone sermonistic grew up during the period of great navigations, when missionary implementation was justified both from the emergence of a common horizon and the reinforcement of a cultural cohesion, promoted by the Christianization of the Western world. Theferore, travel chronicles and missionary parenetics have been united within a generation of a lusophonic literature. In the churches, those who did not have any contact with books, had their travel tickets from the sermons. So is the case with some prayers from Portugal and Brazil, especially in the period when the Lusitan court was transfered to Rio de Janeiro encouraged a more effective rapprochement between these two parts of the empire. That's what happened with Fr. Francisco de São Carlos, a royal preacher devoted to d. João VI, when he construct a special kind of Lisbon at Rio de Janeiro, making the line needed to maintain the Old Regime in Brazil. On the amplification of the boundaries of knowledge, born in Lusophone exchange, this text deals with this imaginary journey to which sermonists and preachers carry the population of these two sides of the Fifth Empire.

Keyword: sacred oratory, maritime expansion, Portuguese empire, Brazilian literature.

O literato Italo Calvino, entre muitas descrições imaginadas na mente de Marco Pólo - o mercador veneziano que no século XIII, aportou no Extremo Oriente, servindo a Kublai Kahna por 17 anos - considera acerca das cidades:

É uma cidade igual a um sonho: tudo o que pode ser imaginado pode ser sonhado, mas mesmo o mais inesperado dos sonhos é um quebra-cabeça que esconde um desejo, ou então o seu oposto, um medo. As cidades, como os sonhos, são construídas por desejos e medos, ainda que o fio condutor de seu discurso seja secreto, que as suas regras sejam absurdas, as suas perspectivas enganosas, e que todas as coisas escondam uma outra coisa. (CALVINO, 1990, p. 46)

Medo e desejo se inscrevem na memória das 55 cidades descritas por Italo Calvino 1990) como a substância que conforma a morfologia das cidades imaginadas. Espelho geográfico, que reflete e é refletido na memória, a corografia das cidades modernas está vinculada ao alargamento espacial e narrativo conformado pela expansão marítima, mas também pelo caráter representativo da cidade que, fundada sob os auspícios de uma repartição ordenada, edifica um patrimônio imaterial (DURAN et DURAN, 2013).

Embora seja trivial verificarmos os mapas urbanos do período pelo estudo da literatura de viagens, Flora Süssekind (1990), assinala que também esses relatos guardam algo de uma ficção nostálgica: no reconhecimento do território alheio, a projeção dos espaços de memória que garantem seja uma sensação de pertencimento e legitimidade para sua ocupação, seja 
uma empatia de cariz imemorial e aspiração universalizante, em que as alteridades rompem as barreiras da identidade. Na fronteira entre o real e o imaginado também se localizam os sermões daqueles pregadores responsáveis pela missão civilizatória no além-mar.

Edificada sob patrimônio histórico, na medida em que a comprovação de seu discurso dependia de argumentos inscritos na tradição e/ou história dos povos, a oratória sagrada representou o papel instrutivo de disseminar uma idéia de passado e uma visão de presente calcada na projeção imaginada da História e de seus espaços diante da audiência. Nessa projeção as cidades ocuparam espaço destacado não apenas porque era necessário entender por onde se moviam os homens que serviam de referência para a conformação do caráter daqueles à quem se destinava o discurso, mas também porque era na distinção da arquitetura e do funcionamento dessas cidades que se propiciava ao público a noção temporal de inserção do homem no espaço, justificando, na cronologia geográfica e patrimonial das cidades, noções como as de progresso e civilização.

Assim como os viajantes que projetavam em novos espaços suas próprias origens, os pregadores fizeram emergir cidades estrangeiras em território de domínio próprio: o discurso religioso. Para Giulio Carlo Argan (2014), uma das principais forças na construção das cidades é o senso estético de seus habitantes. Esse senso estético guia o modo como a cidade é vista, é descrita, é tratada. Não obstante, a ocupação imaginada ou temporária de uma cidade implica no estabelecimento de um acordo entre, no mínimo, dois sensos estéticos: o do estrangeiro e o do nativo. A multidimensionalidade temporal das cidades e cultural dos seus visitantes potencializa esse acordo espacial, configurando a viagem como experiência intelectual, mas também sensorial. O cariz religioso da oratória sagrada, cujo aprendizado estava calcado na graça, acentuam a prescrição sensorial da experiência descritiva da viagem e reforçam, no ressentimento experimentado aquando da imaginação dessa descrição, a necessidade de incluir no panorama cidade visitada, lugares imaginários ${ }^{2}$.

Em 1808, Rio de Janeiro e Lisboa se encontraram. Das roupas e modos dos lisboetas, os cariocas depreendiam as ladeiras da antiga metrópole. Do território pretensamente universal e atemporal da Igreja, os pregadores sagrados se esforçaram por guiar o passeio do grupo heterogêneo e multifacetado pelas ruas imaginadas de um Quinto Império. Frei Francisco de São Carlos foi um desses pregadores que, nomeados como porta-vozes da monarquia lusitana nos trópicos, apontava a ambos os habitantes, os monumentos que justificavam sua união. Tomemos, pois, esse bonde da História, em que à direita da rua Augusta, em Lisboa, podemos ver o chafariz do mestre Valentim, no Rio de Janeiro.

\footnotetext{
${ }^{2}$ Esse movimento é, por exemplo, materializado na construção de ruínas romanas na cidade de Paris no século XVIII. Segundo Jean Starobinski, a Invenção da Liberdade comporta também a dimensão temporal da viagem, trata-se de uma expansão dos sentidos para além do domínio geográfico.
} 


\section{Lisboa/BR.}

"A cidade que ali vedes traçada/ E que a mente vos trás tão ocupada,/

[...] dos luso-brasileiros um dia/ O centro deve ser da monarquia" SÃO CARLOS apud PEREIRA DA SILVA: 1870, p. 533.

Na Capela Real situada à rua Direita, atrás do Paço Imperial, instalado em um antigo convento, é que se assentavam aos domingos do outono fluminense, cerca de 500 pessoas. Um seleto grupo dos milhares de imigrantes portugueses, cujo último destino tinha sido uma Lisboa, então ocupada pelo general Jean-Andoche Junot.

Neste domingo, 1 de março de 1809, frei Francisco de São Carlos celebra o dia de aniversário da feliz chegada de sua alteza real ao Rio de Janeiro rogando pela vida de Nabucodonosor, rei da Babilônia entre 604 e 562 a.C., em cujos sonhos eram decifrados os sinais dos novos impérios:

Um déspota, que não tinha outra lei, que o seu capricho, outro deus que o orgulho de seu coração e que mesmo por um ministério de extravagância dizia ser o criador de si mesmo; um Bárbaro, cuja espada sempre sedenta do sangue humano ceifava as cidades da Síria, como o tufão de vento às folhas secas das arvores; um idólatra que reduziu as cinzas a cidade santa, e deixou cativos os vossos sagrados para as abominações da caldeia, um Nabucodonosor, eis aqui o príncipe, por quem se interessava o povo de deus. Mas em que situação achava-se ele? Ah! Na miséria! Em que país? No seu desterro. Que graças recebia do príncipe? Os berros, a escravidão, o despotismo. E assim mesmo se interessava? Sim e não só se interessava, mas ainda fazia circular cartas ao longe para que se interessassem também os seus compatriotas. Orate provita Nabucodonosor Regis, ET provita pituejus, ut su=int dies corum sicut dies coli superaterram. (SÃO CARLOS, 1809)

A imagem evocada por São Carlos pode parecer contraditória quando comparada ao título da sua versão impressa: Oração de Ação de Graças, recitada no dia $1^{\circ}$ de Marco de 1809 na Capela Real, dia de aniversário da feliz chegada de sua alteza real a esta cidade pelo Frei Francisco de São Carlos. Não é por menos, recomendavam os manuais de retórica para 
pregadores que as orações fossem iniciadas pelo ganho das simpatias dos ouvintes, aonde se deveria inscrever uma empatia entre o orador e a audiência: "não façais como estes maus Oradores que sempre querem declamar mas não falar nunca com os ouvintes: pelo contrario é preciso que imagine cada um dos vossos ouvintes, que falais com ele, em particular" (FÉNELON, 1761, p. 103)

Tratava-se, pois, de buscar nas Sagradas Escrituras as semelhanças com o momento vivido a fim de extrair orientações sobre como sentir, entender e proceder, atualizando essa literatura como recurso de alinhamento moral, e, portanto, estabilização governamental da sociedade. Eis a importância da Oratória Sagrada para as monarquias modernas (DURAN et BRAGA, no prelo), mas também um dos principais meios de transporte de que ela dispunha na época.

Não obstante, ainda que a celebração do sentimento de felicidade seja o objetivo anunciado pelo franciscano no púlpito, era preciso conduzir até lá um grupo coagido pelo perigo a viver em território estranho, era necessário buscá-los lá no sítio da ira e da vingança. Lembremos, pois, que para os autores dos manuais de pregação a ira, em geral, era acompanhada da vingança e motivada, entre outros motivos, pela indiferença, pois, "quando vêem que os outros não fazem caso do seu estado [...] porque o enfermo quer que todos sintam o seu mal"(NOSSA SENHORA, 1792, p. 35). Não obstante,

O modo de excitar nos ouvintes a ira, ou a indignação, é descrever vivamente a atrocidade da acção ou injúria, comparar a inocência e dignidade do ofendido, com a vileza e atrevimento do ofensor: expor os graves danos e perniciosas consequências que se seguem da injúria. (NOSSA SENHORA, 1792, p. 35)

Seguindo essa linha argumentativa, São Carlos empreende uma tentativa de reconforto e focaliza o objetivo do discurso, no intuito de abrandar os sentimentos dos ouvintes:

Se um povo santo, depósito então de verdades do céu, não se julgava dispensado de orar por um rei bárbaro, que o tinha em perros, se o apóstolo nos velhos dias da igreja nascente ensinava aos primeiros discípulos da Fé, que ora sim pelos césares de Roma, os césares que tinham jurado a ruína da mesma igreja, os césares, em cuja cronologia aparecem escritos os nomes dos calígulas, dos neros e dos heliogrados, os nomes que só por si inculcam o do crime e da tirania, quais devem ser 
logo os nossos votos, os nossos sentimentos, o ardor de nossas lágrimas pela conservação de um príncipe, que faz a alegria de seu povo, e que pela sua religião é o modelo de todos os príncipes? (SÃO CARLOS, 1809)

No povo santo, o orador incute uma dupla camada de empatia: primeiro, alude à população que ficara em Lisboa e não se julgava dispensada de orar por um rei bárbaro, unindo, pela presença que a lembrança garante, os dois lados do Atlântico. Contando com a presença daqueles que ficaram em Lisboa em sua nave, o orador dobra sua audiência quando permite uma comparação entre os pesares de residir livremente na babilônia tropical em detrimento do que seria viver na terra sitiada por Junot e Beresford, mas também quando convida a representar a cidade de origem nas ruas locais, recriando Lisboa no Rio de Janeiro.

Nessa paisagem imaginada, que templos se não devem consagrar? (SÃO CARLOS, 1809), pergunta-se São Carlos trazendo os ouvintes de volta do campo de guerra. Como a monarquia portuguesa poderia sustentar sua identidade, sua legitimidade despida daqueles signos que fomentavam e lastreavam seu poder? Como transportar Lisboa para o Rio de Janeiro sem mover a Torre de Belém? O padre nos responde: "vossas graças vos transportareis de sua glória" (SÃO CARLOS, 1809).

A memória dos sucessos lusitanos iria, pois, consubstanciar o poder real. Monumento discursivo representado num "pedaço de céu semeado de estrelas, visto em uma noite serena" (SÃO CARLOS, 1809), São Carlos situa no imaginário o endereço da memória, na Capela Real fluminense, a Sé de Lisboa. Para Manoel de Almeida e Souza Lobão (1815), esse imaginário não era, entretanto, desprovido de valor ou mesmo materialidade:

Um governo monárquico como o nosso, sendo de todos o mais sólido, tranqüilo e interessante aos povos, conforme o melhor sentimento dos políticos, depende que nele hajam grandes personagens, duques, marqueses, condes, viscondes, barões, etc., como outras tantas colunas do mesmo reino, e que são como membros do corpo moral, e político do Estado, de que o rei, e a sua coroa é a cabeça. Deste princípio é um necessário consequente que estes grandes do reino, estes membros do corpo político, estas colunas do Estado, tenham bases sólidas em que se sustentem, quais as riquezas; porque sem elas, à proporção das suas dignidades, não podem subsistir, nem conservar o luzimento, que a proximidade do trono lhes influe, e deve influir. Sem riquezas se reduzirão a obscuridade, e ao abatimento.(LOBÃO, 1815, p. 5). 
Note-se que, sem o primeiro aspecto, não se sustenta nem a segurança, nem a economia do reino e, sem o segundo, o equilíbrio das relações sociais no interior do reino ficam comprometidas. De modo que, se D. João VI trouxe para o Brasil sua corte, isso significa que carregou consigo suas divisas, seus monumentos, aqueles que garantiriam material e moralmente a representatividade, ou seja, a importância de seu governo.

Paralelamente, Roma integra a paisagem com seus "calígulas, neros e heliogrados" e o que esse campo de flores faz aí? Reforça duas importantes vigas para a ponte que permite a travessia proposta. Primeiro, traz à tona os revezes do Império e a sua capacidade de manterse ou reconstruir-se sobre suas ruínas. Depois, rememora o lócus da Igreja e, com ele o do orador, fazendo convergir, no púlpito, o duplo caráter da oratória: político e religioso.

Imaginário que também foi edificado pelos beletristas e viajantes em sua literatura, aonde não raras vezes as vozes dos pregadores soavam como cantilena despropositada:

fui forçado a assistir uma missa numa capela próxima, onde o oficiante é um velho vigário, amigo íntimo e visitante diário da família. Leu o serviço religioso em latim, com voz grave e monótona. Em algumas partes somente o movimento dos lábios indicava estar lendo suas maneiras eram impressionantes, salvo o sinal da cruz, mesuras, reverências e beijos, que eram bastante pueris a meus olhos e não poderiam mesmo ser feitos de forma graciosa por um homem vestido de mulher, com espectadores às suas costas. As cerimônias terminaram antes que o cansaço ou a indiferença fizessem desejar seu fim(EWBANK, 1976, p. 57).

Habitado por diferentes sons e línguas, o Rio de Janeiro, aliás, também tinha sido invadido pelos franceses. Revirada por Duguay Troin, em meados de 1710, a cidade teve que fortificar suas entradas, os moradores da beira da praia recuaram aos poucos continente adentro, ainda assim, a cidade não ficava longe do mar (SPIX et MARTIUS, 1976, p. 43).

Um breve passeio pela cidade mostraria poucas vendas, duas escolas: o colégio São José e o colégio São Joaquim, e muitas igrejas. As casas locais podiam ser dimensionadas em duas escalas: alguns poucos casarões - cuja suntuosidade era medida pelo número de janelas; e muitas casas térreas. As janelas seguiam um estilo mouro, também recorrente em Portugal, eram cobertas por gelosias de madeira. As telhas eram colocadas umas sobre as outras sem argamassa, à moda chinesa - levemente inclinadas no eixo central e planas no restante. As 
paredes eram quase sempre caiadas de branco, de onde vinha a alcunha de seus habitantes (CAVALCANTI, 2004).

A simplicidade e o exotismo da paisagem penetravam no interior das casas com poucos móveis e adornos. Uma sala de estar, onde também se costumava comer; um corredor que nos levaria à cozinha - no caso de uma casa térrea, pelo caminho os quartos, na verdade, alcovas, pois não possuíam janelas. A cozinha, onde o visitante mais atento poderia notar alguns escravos fazendo comidas e preparando quitutes (BICALHO, 2003).

A presença dos escravos acentuava a diferença mesmo entre a metrópole e a colônia (RUGENDAS, 1976). Isso porque desde a época de Pombal, o tráfico de escravos para Portugalmetrópole tinha sido proibido em prol do povoamento e da concentração dessa mão-de-obra no Além-mar (HESPANHA, 2010). Nos relatos de viajantes como John Mawe, Luccock, Ebel, Eschwege, Gardner, Burmeister, uma recorrência é comum: estes negros cantarolam ou berram durante todo o tempo e por todos os espaços por onde passam (LEITE, 1997).

Essa oralidade ecoava pela rua da Quitanda, local onde se estabeleciam as negras de ganho e forras no intuito de vender ou trocar suas mercadorias. Pela rua do Ouvidor, aonde se instalaram os modistas. Pela rua do Valongo, onde era realizado o mercado de escravos. Pelo Terreiro do Paço, quando se dissipava entre os murmúrios dos que se aglomeravam para serem recebidos na cerimônia do beija-mão, muitas vezes, para reivindicar a devolução de uma casa que lhe fora tomada pelos reinóis, na transferência da corte (CAVALCANTI, 2004).

Disputa pelo espaço que se fez notar na substituição das gelosias por balcões de madeira, na limpeza mais acurada das ruas, na iluminação argêntea da noite, na multiplicação dos chafarizes pela cidade, mas também na reivindicação do investimento feito na cidade, fosse ele econômico ou cultural:

Se os ingleses foram os primeiros a desenvolver entre os brasileiros o gosto pelos aperfeiçoamentos industriais, se foram eles que imprimiram sobretudo do país essa atividade comercial (...) é a nós - os franceses que compete reivindicar a anterioridade ou iniciação nas artes e ciências, que um povo deve sempre a outro povo, e que faz, para sempre, época na história de seu desenvolvimento social (DENIS, 1980, p. 115).

$O$ verniz francês dado às paisagens e costumes fluminenses era compartilhado com os portugueses e seria acentuado pela arquitetura da primeira missão francesa ao Brasil, em 1816, sob a liderança de Grandjean de Montigny. Sua expressão, aliás, ganhou fôlego na oratória com a sobreposição da literatura francesa em relação à portuguesa: 
Entregando-se à cultura da eloqüência, o jovem orador brasileiro era condenado a ficar na obscuridade, estudando os oradores portugueses, cujos sermonários eram comuns entre nós; ou procurar na leitura dos pregadores franceses as inspirações, de que carecia para ilustrar o seu espírito, e abrilhantar os seus discursos (MONTE ALVERNE, 1858, tomo I, p. XII).

Nesse sentido, a multiplicação de vozes não implicou numa diversificação do seu suporte, mesmo quando destinadas ao incremento da cultura, validando, a oratória sagrada como "um mass media poderoso, de enorme eficácia colectiva" (LUZ, 2005, p. 114).

Situado entre as coordenadas do poder monárquico e religioso, afigura-se o pregador real frei Francisco de São Carlos. São Carlos nasceu em 13 de agosto de 1763. Aos 13 anos ingressou na Ordem Seráfica da Imaculada Conceição e aos 19 anos foi mandado para o convento São Boaventura, na vila de Macacú - Rio de Janeiro. Em 1801 foi nomeado professor de eloqüência desse Convento, mas foi no Convento Santo Antonio que granjeou a fama de pregador. Na casa de Santo Antonio,

A cela que pertenceu a frei S. Carlos está situada na extrema esquerda da face principal do convento e dela são as últimas duas janelas de peitoril que ali se vêem. Por cima, no segundo andar, tem ela o painel e altar de N. S. da Assunção, que havemos de contemplar mais tarde. (MACEDO, 2004, p. 231)

Nossa Senhora d'Assunção da Virgem, aliás, foi a santa à quem São Carlos dedicou uma versão lusófona do gênero épico, tal como atesta Sérgio Buarque de Holanda (1991):

A composição do poema deve ser pouco posterior a 1801, ano em que, ao regressar de Minas, é convidado a reger a cadeira de eloqüência sagrada no Colégio São José, no Rio de Janeiro. Sabe-se que essa composição deve ter coincidido com o período de sua primeira guardiania, exercida no Convento de Bom Jesus da Ilha, depois disso seria ainda guardião de Nossa Senhora do Espírito Santo. Pouco antes de morrer, em 1829, no 
último colóquio com seu amigo e confrade Mont'Alverne, teria dito que a composição de uma verdadeira epopéia não entrara de início em seus planos. Começava por devoção e desenfado, escrevendo hinos dedicados à Virgem Santíssima, só depois viera-lhe a idéia de dar forma unitária a essas peças soltas. À devoção cristã juntou-se então o amor da pátria para enriquecer todo o conjunto de algumas cenas brasileiras, a exemplo do que, em casos tais, haviam feito seus predecessores. (HOLANDA, 1991, p. 67)

Seu falecimento é uma incógnita, alguns autores aventam o embarque do frei junto à família real para Lisboa em 1822, outros atestam sua morte em 6 de maio de 1829 no Rio de Janeiro (DURAN, 2010). Assim como os registros desse óbito, também os poemas à virgem tiveram destino incerto, como lamenta o companheiro de púlpito Januário da Cunha Barbosa, ao referenciar a perda da obra do frei em seu discurso para a edificação de uma história nacional na inauguração do Instituto Histórico e Geográfico Brasileiro:

Ah! Se ainda assim mesmo tantos escriptos de illustres Brasileiros fossem dados á luz publica, ou conservados em archivos, para que a posteridade delles se aproveitasse, talvez que então se podesse realisar em parte, a doutrina de Cicero, quando chama a historia testemunha dos tempos. [...] Mas, por desgraça nossa, em desardo nosso patriotismo, temos visto, e continuamos a ver, sepultarem-se muitos escriptores de merito como abraçados com as suas produções litterarias [...] A ignorancia ou descuido de seus herdeiros as entrega logo á coragem dos annos; seus nomes vagueão por algum tempo sobre as suas campas, até que de todo se esvaecem, perdendo-se até mesmo a noticia dos lugares em que estes escriptores nascerão, ou honrarão por suas gloriosas fadigas. (BARBOSA, 1838, Par.7,8 e 9)

De figura "bela e vistosa" (SILVA, 1870, p. 527), frei Francisco de São Carlos foi nomeado pregador real no ano em que apresentou o sermão que voltamos a acompanhar:

Em todos os tempos aqueles povos que se frisavam de mais polidos e religiosos, procuravam sempre imortalizar os seus príncipes e as pessoas que lhes eram mais caras. Roma com seus Aphoteoses e Egito 
com seus aromas. Persuadidos os orientais que os cadáveres livres da infecção ainda viviam para os preservar desse opróbio, o mais humilhante da natureza, chamavam a seu socorro as rezinas da Arábia. Nos porém, que vivemos em séculos de melhores luzes. Nós, que temos a glória de cultores de um deus, que não é surdo, devemos confiar nas nossas orações, como o melhor preservativo da vida e o mais eficaz antídoto da morte. É este o Bálsamo que preserva quando vivo, que imortaliza quando morto. É este aquele pomo da vida plantado no paraíso para dilatar o dias dos nossos primeiros pais, já tão dilatados. $\mathrm{E}$ este finalmente aquele perfume que São João viu no apocalipse ser oferecido por um anjo sobre o altar de vidro do trono do altíssimo. (SÃO CARLOS, 1809)

Voltando a atenção do público para a importância da oração e, por conseguinte, solicitando de sua audiência a concentração máxima nos atavios de seu discurso, conclama "oremos pois pela conservação da família real e demos graças ao senhor de a ter salvado de tantos perigos" (SÃO CARLOS, 1809). E, como "graça deslizando com toda a espontaneidade por um caminho de flores" (PEREIRA SILVA, 1870, p. 543), demarca, na moção das paixões em função da defesa das cidades, o território da parenética:

Se eu não desempenhar a grandeza do objeto, contentai-vos com o atrevimento de o inculcar. Em matéria tão sublime o ser ousado, é já ser eloqüente. Eu me satisfaço com excitá-la nos vossos corações. Serei semelhante a esses círios de pequena luz, mas que na extremidade da cama manejados por uma Mão destra em breves instantes iluminam todo o templo na hora de sua solenidade. As aves não são capazes de defender as cidades, mas aquelas que estavam no capitólio, despertando as guardas com seu estrepito, sairão a Roma do furor dos franceses. (SÃO CARLOS, 1809)

As cidades que São Carlos defende são "as belas províncias, que o Tejo e o Douro regam e que passam pelo jardim da Europa", onde um "punhado de tribos espalhadas pela últimas praias do ocidente" foi vítima do "lobo da fábula [...que...] achou na sua mesma fome o pretexto [...] de devorar o cordeiro"(SÃO CARLOS, 1809). Menoscabados pela arrogância napoleônica, "os portugueses apesar da sua natural bravura e da glória de que estão de posse há muitos séculos" viram suas terras invadidas por "batalhões, a fogo e a vinagre", e rasgando "as pragas dos 
Pirineus" foram empurrados com "susto e terror até as portas da pátria dos Pachecos, e dos Albuquerques" em nome da "herança dos descendentes de Roberto, rei da França" (SÃO CARLOS, 1809).

Nessa história do cerco de Lisboa, São Carlos defende que a fuga do continente europeu configurava uma medida protetiva "da princesa das províncias, a nova Tiro, a Rainha dos Mares, aquela que enviou anjos velozes as extremidades da terra para propagar vosso santo nome", para que não fosse "levada em triunfo ante o carro do usurpador", impingindo a toda a população "tributos insuportáveis" (SÃO CARLOS, 1809). Tratava-se, pois, de salvar a rainha, salvando a casa mater, no limite, o reinado, perpetuado na figura do príncipe. Por essa razão, perguntase o Orador:

Um filho digno de tal mãe, um príncipe talhado ao molde do vosso coração, o David dos nossos dias, cujo único prazer e o culto e o triunfo da arca santa aquele que faz reinar em seu trono o deus, por quem ele reina, aquele que por sua religião edificante tem conservado a virtude, $\mathrm{e}$ ao santuário a decência e respeitosa dignidade, que lhes não pode tirar a libertinagem, este filho terá a mesma sorte? (SÃO CARLOS, 1809)

Foi oferecendo à audiência o benefício da dúvida, que esse embaixador do rei dos reis na terra - tal como a Igreja romana havia situado o serviço eclesiástico em Trento, e afixado no direito canônico a regulação entre os povos submetidos a diferentes monarquias (MATOS, 2004)-, apresentou seu parecer: "não, grande deus, nós somos o vosso povo, vós o jurastes por nós. Mesmo no campo d'Ourique. Algumas vezes nos tendes ferido e castigado, mas nunca apartastes de nossas cabeças a vossa ternura paternal". Parecer ao qual inclui um atenuante: "vira um desconhecido da caldea, príncipe que ainda ontem nasceu do pó que deve ser preso a vosso ungido?” (SÃO CARLOS, 1809). Duplamente não, o governo militar de Napoleão não constituía o Estado de Ordens reconhecido pela monarquia portuguesa e, tampouco pela Igreja Católica que, na presença de Pio VII, havia assistido a uma coroação que não procedeu (LENTZ, 2008), portanto, não, a França não tinha o direito de submeter Portugal nas regras vigentes.

Notando a apoteose desse intróito, o frei verifica que "já brotou o ramo douro que faz da alegria de nossos pais" e roga para que "não se apaguem de todo agora as últimas lâmpadas de Israel", isso porque ele pretende apresentar ainda mais uma prova da ilegitimidade da expansão napoleônica, evocada a partir disputa sobre a herança "do santo, do magnânimo, do imortal conde d. Henrique" (SÃO CARLOS, 1809). 
Henrique (1069-1122) nasceu no ducado da Borgonha, entregue em 1032 a Roberto II, rei da França, seu bisavô. O tio-avô de Henrique fora não mais que Hugo (1024-1109), cardeal responsável pela Abadia de Cluny durante a chamada reforma gregoriana, que procurava uniformizar e ampliar a divulgação da liturgia romana no ocidente, pressionando uma cisão entre cristãos e muçulmanos. Por volta de 1087-1092, Henrique recebeu a tenência do condado Portucalense, na Península Ibérica, então governada por sua tia Constança e por Afonso VI. O rei de Leão e Castela, professava o ideário cisterciense e pendia para Raimundo, com quem casara sua filha Urraca, quando se tratava da ascensão ibérica do Douro ao Tejo. O espaço estava ameaçado pelas tropas marranas, cujas vitórias, em 1093, levaram o rei a incentivar o bom desempenho bélico de Henrique concedendo-lhe a mão de sua filha, Teresa, ainda infanta (AGUIAR, 1867, p. 175).

Ao que parece, o casamento com a filha ilegítima e, portanto, morganática, isto é, sem direitos de sucessão ao trono, do rei de Leão e Castela não esmoreceu a fé do pai de Afonso Henriques, reputado como fundador de Portugal, após sua emancipação da Galiza, na batalha de São Mamede (1128). Pelo contrário, tal como compete a um estrategista militar, Henrique atuou em várias frentes. Do Douro ao Minho, articulou as famílias Maia, Ribadouro, Sousa, Bragança e Baião respeitando os costumes feudais ali vigentes e reivindicando a sede do Bispado à Braga, em detrimento de Santiago de Compostela. Em Coimbra, reconheceu a estrutura urbana arregimentada na conformação dos Estatutos Universitários. Na Beira Litoral, se dispôs a negociar o poder junto aos muitos moçárabes ali residentes. No Mondengo, parece ter exercido seu poder maior (AGUIAR, 1867, p. 188).

Descendente da dinastia capetíngea - Roberto II fora pai de Hugo Capeto -, integrante da casa real de Leão e Castela - por consangüinidade e matrimônio -, representante da reforma gregoriana, soldado de Deus na guerra contra os marranos, a legitimidade do progenitor do fundador de Portugal era, para São Carlos "um tecido de provas, e de misericórdias do céu", profundamente gravado também nos corações dos "vassalos brasileiros" que, descendentes dos "Aberramans e dos Almonçores [...] escondiam nas entranhas dos montes as relíquias dos mártires para as salvar dos insultos muçulmanos" (SÃO CARLOS, 1809).

Tal como insulto muçulmano, ou seja, infiel, distante da verdade, o "Emissário do Usurpador", vulgo, Junot: "profere esta blasfêmia atroz: a casa de Bragança cessou de reinar em Portugal: lançou a sorte contra si: atraiu fogo a sentença de sua reprovação e começou a cavar o túmulo de sua ruína". Atestando, pois, a inverdade da sentença, uma vez que d. João VI, embora tivesse deixado Lisboa, não havia sido destituído da regência, São Carlos defende, pois, como Fénelon, que a História é um dos sustentáculos do poder monárquico e que seu uso pode legitimar ou não o trânsito de valor na economia do poder vigente. Infiel, ao proferir uma inverdade, Junot comete um dos pecados dos historiadores: "O historiador que me quer ensinar o que eu vejo que ele não podia saber; faz que eu duvide dos mesmos fatos que ele sabe". (FENELON, 1761, p. 324). 
Para fugir da dúvida, o historiador oitocentista baseado nas prerrogativas parenéticas, muitas vezes recorria aos artifícios da eloquência: na falta de dados, o efeito sentimental da narrativa, propiciado pela riqueza metafórica, complementava a compreensão do público. Esses artifícios, note-se, não eram utilizados apenas por sermonistas, ainda que sua estrutura fosse decorrente da oratória sagrada, tal como se pode notar na descrição da mesma passagem pelo homem de negócios e política que foi o Visconde de Cairu:

O Benefício que vou expor, transcende todo o elogio e cálculo por compreender o Heróico Sacrifício do Senhor D. João VI, para salvar a coroa, a real família, a monarquia, a Nação e a sociedade, das garras do Tigre Corso, e dos seus aderentes, filhos do país desmoralizado, e fértil em monstros, só distintos em natureza ferina, pela súbita metamorfose da revolução, que, como a circe da fábula, transformava em brutos a quantos tocava (CAIRU, 1818, p. 38).

Ainda assim, o infiel Junot feria um segundo princípio monárquico, igualmente, fundado na memória do conde d. Henrique. Nas Linhagens do Estado Absolutista (ANDERSON, 1999), o poder emanava não do local de nascimento - no caso, a Borgonha -, mas sim do posicionamento genealógico, da ordem de nascimento, ou seja, trata-se de um problema de escala à que a realidade é reduzida. Na escala de um general napoleônico, o dínamo do poder se situa na origem do território de poder. Na escala de um monarca moderno, a mobilidade desse dínamo é assegurada pela significação (simbólica) desse poder, configurando, portanto, um embate entre a cidade $\mathrm{x}$ a corte, a linhagem $\mathrm{x}$ a origem. Problema que, para os portugueses nascidos no Brasil, não parecia configurar um impeditivo para a governança:

A casa de Bragança não caiu: novo dia se lhe abre no Novo Mundo: ele renasce para gozar de perspectiva mais esplendida do que tem ornado a sua brilhante carreira....A respeitável Nação portuguesa, representada pela sua real cabeça, e principais membros, realizou algumas das mais felizes ficções da poesia épia; e espantou o mundo, assoalhando o magnífico espetáculo de um povo deixando, por comum acordo, a terra que lhe deu nascimento, e os túmulos de seus pais, para procurar independência em outro hemisfério.(CAIRU, 1818, p. 76). 
Destarte, São Carlos afirma que "o tirano cometeu um grande erro, e envenenou todos os planos do déspota seu amo", pois os "rios de lagrimas e sangue de inocentes" comprovavam que se tratava de um "roubo" (SÃO CARLOS, 1809), que já estava em vias de ser ressarcido:

Enfim, rasgou-se o véu, abriram-se os olhos, conheceu-se a pretendida proteção, e os portugueses forcejaram por sacudir o julgo de perto. Já por todas as nossas províncias do norte tremula o estandarte da liberdade $\mathrm{e}$ retumba a voz do patriotismo. Já se limpam as armas velhas, que a paz e o vício tinham feito pasto de ferrugem e que apenas tinham escapado ao olho ciumento do tirano. Fundam-se novas lanças, novas espadas; provam-se arneses, ajustam-se malhas. A cada passo retinem as bigornas debaixo dos golpes de martelo. $O$ camponês honrado desce dos montes, e vem oferecer a pátria o filho robusto, sócio de suas fadigas, e converte o arado em espada. Lá se aprende esta arte fatal, que com o nome da tática, é um flagelo destruidor da humanidade: ferve a guerra em todo o Portugal (SÃO CARLOS, 1809).

A guerra de fato fervilhara durante os 9 meses da ocupação francesa (HESPANHA, 2010), mas no momento em que a Oração de São Carlos era proferida, a cor brasileira já dourava Lisboa sob os auspícios do decreto de Abertura dos Portos, firmado em 28 de janeiro de 1808, pelo príncipe regente:

\begin{abstract}
Não será assim, a nação britânica conhece as leis da gratidão, ela as respeita, ela as adora. Jura pois pelo que há de mais sagrado sobre a terra, pelo cetro de seu soberano, pelo curso inviolável de seu parlamento, que ou o seu nome se há de apagar da face da terra, ou há de ser desafrontado o seu augusto aliado. (SÃO CARLOS, 1809)
\end{abstract}

Com as tropas britânicas marchando sob a mancha, "eis aqui senhores, um novo gênero de misericórdias" em que "o paciente já de alguma sorte triunfa antes mesmos de ter conseguido o sucesso de seu feito" (São Carlos, 1809). Nessa altura, "já as bandeiras da união tremulam nas venturosas praias", o português, "ao chegar ao vosso exército [...] só achou o campo", pois o tirano "adianta[ra]-se a tomar os fastos aos nossos aliados" (SÃO CARLOS, 1809). Aos "generosos britânicos", a quem caberia "equilibrar a balança da Europa", foi concedida ainda a delimitação 
do Tratado de Cooperação e Amizade que, firmado em 1810, assegurava à Grã Bretanha os principais benefícios da abertura dos portos de Portugal no Brasil.

\title{
2. Rio de Janeiro/PT
}

No Brasil, os navegantes portugueses de 1808 eram, pois, conclamados pelo frei a verificar que a "se este sucesso tivesse acontecido nos dias da fábula e do heroísmo" constituíriam "ilustres argumentos para suas epopéias", devidamente assegurados por "deuses e deusas do Olimpo", tal como ocorria aos árcades locais na celebração da terra que os recebeu:

\begin{abstract}
Aquela antiga capital, mãe de todas as cidades do Brasil, donde vieram seus primeiros fundadores, ó Rio de Janeiro, como de Alba os fundadores de Roma, e de Tiro os primeiros de Cartago, desce do alto de seu monte, como uma nova Ceres está cravada de torres, e corre atropeladamente as margens do golfo, que a larva a prostar-se e a adorar o bendito que vem em nome do senhor (SÃO CARLOS, 1809).
\end{abstract}

Essa celebração, se assemelhava aquela experimentada pela audiência porque significava para os habitantes dessa parte do Império também uma libertação:

\begin{abstract}
Ah! Já não são mais esses viscegerantes de suas vontades, já não são mais esses ilustres da nação, que em seu nome a vem reger, é seu soberano em própria pessoa, são estes sereníssimos príncipes, estas augustas princesas da imortal dinastia bragantina, mimosas rosas que se vão abrindo com o orvalho da graça e dos risos juvenis, para serem um dia a mente dos palácios dos grandes príncipes, e as esperanças das cortes estrangeiras (SÃO CARLOS, 1809)
\end{abstract}

Libertação conquistada pelo Príncipe pela experimentação de provas rudes, é certo, mas que também conferiam lastro à sua honra ${ }^{3}$, e imprimiam amor nos corações de seus servos. Amor que, contraposto ao temor, disputava na literatura moderna o posto de eixo articulador

\footnotetext{
${ }^{3}$ A lógica era a mesma que forjava nos trabalhos de Hércules, o heroísmo de sua figura; nos sacrifícios de Cristo, a comprovação de sua filiação. Para São Carlos, "O soldado conhece-se no combate, o Sábio na disputa, o piloto na tormenta, mas o justo na tribulação. As boas obras dão direito ao céu, mas os trabalhos são quem o asseguram: reinar deste modo não é reinar nos corações? Eis aqui um triunfo que glorifica a S.M.R. mais do que se tivera conseguido novas vitórias". (SÃO CARLOS, 1809)
} 
das monarquias ocidentais. Vale lembrar que os sentimentos ainda integram o quadro de argumentos razoáveis para a História da época, mais uma vez, como nos lembra o Visconde de Cairu acerca do mesmo evento reportado por São Carlos:

Os sentimentos dos habitantes de Portugal são mais fáceis de se imaginarem que de se exprimirem com a saída da corte para o asilo dos trópicos. Os sentimentos dos habitantes do Brasil, ainda que uníssonos aos da mãe pátria nos pontos essenciais, podem se melhor expressar, por desassombrados do terror da invasão, e recebedores do grande benefício da presença de seu príncipe.(CAIRU, 1818, p. 64).

Diferente de Cairu, na cosmologia de São Carlos, quando d. João VI bate em retirada de Lisboa, ele se furta a imprimir sua força pelo temor, caindo em seu oposto: $o$ amor. $O$ amor da conciliação que, tal como apregoado pelos ingleses desde Thomas Morus, na Utopia, constituía uma das principais ferramentas políticas da monarquia portuguesa moderna (CARDIM, 1999) e servia de argumento suficiente para a legitimação do poder real, mesmo quando da transferência do lócus territorial desse poder, uma vez que, no complicado sistema de linhagens monárquicas, a origem nobre e a predestinação do soberano se sobrepunham ao endereço de origem desse poder, ainda que também se aplicasse, pouco à pouco, às cidades:

O Brasil devia esconder seu seio o penhor mais seguro da estabilidade do trono português. As memórias estupendas, que ilustraram a longa esteira de seiscentos anos, ia ser confiada à sua guarda. Quem ignora este celebre acontecimento? Quem não viu este sucesso famoso? Tudo pressagiava o futuro mais lisongeiro. A liberdade do soberano antecipava os nossos votos. Parecia que eles haviam tocado seu termo; $\mathrm{e}$ a nossa sensibilidade, como que estava esgotada. (MONTE ALVERNE, 1858, tomo II, p.278).

Esgotados pelos sentidos, os fluminenses esforçavam-se não apenas por entender o outro, mas também por assemelhar-se a ele. Nesse processo, ainda que estender a predestinação às cidades implicasse em absorver alguns dos ideais que levaram Junot a legitimar o entendimento de que a saída de d. João VI de Lisboa significava a vacância do trono, o que São Carlos e os demais pregadores reais defendiam era que inscrever esse 
entendimento sob a legitimidade consagrada da predestinação real no intuito de negá-la não era válido, porque corrompia a validação de ambos os princípios.

Ora, a regra cristã observava normas e princípios que, pela disciplina, aplicados à sociedade por si só não significava a virtude. Para os oradores sagrados, o vício também poderia ter como origem o mal, inscrito na intencionalidade dos atos. Nesta lógica, quando São Carlos revisa a mirabolante viagem dos reis, digna de comparação às odisséias do Olimpo, em nenhum momento a desvincula das boas intenções reais: salvar a mãe, manter o reino, pacificar a pátria. Sinais da predestinação baseada no amor cristão daqueles que poupam a vida dos seus pelo sacrifício pessoal, no caso, real, âmbito em que atentar contra a honra - tal como d. João VI fizera arriscando sua reputação carregando "a augusta mãe por cima das ondas do oceano" (SÃO CARLOS, 1809) - equivalia a cometer um suicídio político (HESPANHA, 2010).

A transferência da corte portuguesa para o Brasil reforça e se inscreve, portanto, num dos frames de uma transição mais ampla das perspectivas governamentais da Europa moderna que, embora já tivesse atravessado uma Revolução Francesa, ainda estava atada a um Estado de Ordens, tal como demonstrou o argumento de São Carlos acerca da ilegitimidade do reinado de Napoleão.

Nessa transição é possível divisar dois vetores paralelos: por um lado a desvalorização da Igreja como porta-voz da liturgia política que sacralizava a monarquia, retirando do âmbito religioso e, portanto, do universo vocabular das paixões, os regimes de saberes necessários ao exercício do poder. Ao seu lado, um discurso de paz que, baseado no amor, e não na coerção exercida abertamente pelo rei, será coroado em Westfália, assim como Napoleão, sem a presença do papa.

Da cidade do Rio de Janeiro, São Carlos parece estar atento a esses movimentos, assinalando um novo tempo para as monarquias ocidentais:

Minha imaginação parece viajar um pouco pelo continente da Europa, as suas cortes estão todas presentes aos meus olhos. Eu procuro Veneza, já não existe. Aquela república tão afamada, chamada rica, menos pelas pérolas das conchas de suas naus do que por ter sido em outro tempo a senhora de todo o comércio do levante; não só está viúva de seus Doges, mas nem já tem nome entre nações independentes. Vejo a Holanda, que saiu de suas dunas para ser a rainha dos mares, e que tanto se engrossou com os nossos infortúnios, beijando em silêncio os grilhões que a oprimem. Se lanço depois disto meus olhos pela pátria dos Fredericos, eu vejo o terror e o luto derramado pelo trono destes augustos mestres da Tática. Se contemplo a Alemanha, a Alemanha sempre tão aguerrida, 
sempre tão disciplinada, vejo-a toda ocupada em medicar feridas, que ainda gotejam sangue. Se considero ainda esses heróis, que o seio de uma pequena ilha do mediterrâneo eram como uns dragões do mar, que assustavam as suas algarenas e puseram sempre um freio vergonhoso à soberba da Porta Otomana, que os vejo sem domicílio certo, vagos errantes pelas cortes do continente. Se procuro enfim o soberano de Nápoles, eu vou dar com ele acantoado em uma ilha; apenas tendo por baluarte de sua augusta pessoa as mãos de seus aliados. Que direi do rei de Sardenha? Do Grão Duque da Toscana? Ah! Cederam seus tronos à Barbara pureza, e ambição dos Gengis Khan dos nossos dias, enquanto o céu justo não lhes restitui. No meio deste transtorno geral, em que vejo tantos príncipes ou banidos de seus estados, ou despojados de seus tronos, ou suportando o peso de uma vida particular, eu procuro o meu soberano, e vendo-o tranqüilo e feliz no meio de nós mesmos, então eu exclamo: Ó Deus, vós amais o príncipe de Portugal, pois que é o Noé, que salva no meio de tão grande dilúvio. (SÃO CARLOS, 1809)

Redentor do Antigo Regime nos Trópicos, para São Carlos, d. João VI reina no "reinado do Céu, [...] de deus, [...] dos grandes príncipes" (SÃO CARLOS, 1809) e "quando os corações proclamam os soberanos, os soberanos devem contar certo com a felicidade de seu governo, porque também contam com a segurança dos corações" (SÃO CARLOS, 1809), condição essencial para a estabilidade e a manutenção dos reinados.

Para São Carlos, d. João VI, além de assegurar seu reinado pela força normativa do Regime, contava com os corações dos vassalos "das colônias o acolhem com lágrimas de ternuras, [e com] os da Europa os defendem em preço de suas vidas" (SÃO CARLOS, 1809). Nessa valorização do terceiro estado dois sinais: o primeiro se refere à limitação de seu espaço no discurso, o segundo à sua presença - que aumentaria com a Revolução do Porto, em 1822.

Não obstante, destaque-se a importância da divulgação das “verdades" expostas: "em todas as partes, onde se respeita o nome lusitano, onde se fala a linguagem portuguesa, onde triunfam as sagradas quinas da nação, [...] em todas as quatro partes do mundo" (SÃO CARLOS, 1809). Ora, o exercício do poder monárquico também dependia de seu reconhecimento, de sua representação e o gradiente de sua difusão deveria ser proporcional à sua força. Bradar a manutenção da monarquia mesmo nas franjas do oceano Atlântico significava demarcar sua importância no território político europeu.

Restava saber, para os habitantes do Brasil, se era chegada a hora de galgar "o degrau honorífico tão longamente aguardado" (MONTE ALVERNE, 1858, p.278). No Rio de Janeiro/PT "rotos os vestidos, desgrenhados os cabelos" o povo "confia à Vossa intrepidez, e ao vosso arrojo 
seus mais caros interesses!" (MONTE ALVERNE, 1858, tomo II, p.268). "Esta risonha perspectiva era apenas um ensaio de nossas prosperidades. Um fato nunca ouvido ia ser entregue à história das nações. O Brasil devia esconder seu seio o penhor mais seguro da estabilidade do trono português" (MONTE ALVERNE, 1858, tomo II, p.278).

\begin{abstract}
Sim, senhores, está é a história doméstica da nação, que se deve transmitir de pais a filhos, que se deve escrever nas fímbrias dos nossos vestidos, nos portais das nossas casas. Suas altezas salvos de tão grandes perigos, triunfantes dos elementos, tranqüilos em porto seguro, no meio dos seus vassalos, na posse de seus estados. Só isso? Sua herança reivindicada em menos de um ano, desassombrada dos invasores com tanta presteza, que pode dizer um viajante: Eu ontem passei por Portugal, achei-o todo consternado pela invasão dos franceses, tornei a passar no outro dia, e achei-o evacuado, todo alegre, gozando da sua antiga liberdade (SÃO CARLOS, 1809).
\end{abstract}

\title{
Considerações Finais
}

Tal como na metáfora que serve de título ao presente texto, a história brasileira recebeu maior impulso com o trânsito real através do oceano. Flanando sobre um mar de incertezas e construindo monumentos imaginários, sermonistas como São Carlos se esforçaram por dar a conhecer as condições que traziam a corte para o Brasil, sua história pregressa, bem como as expectativas que se podia alimentar com essa transição. Se esta não foi a melhor história do Brasil, como depois apontaria Varnhagen (1957), foi a primeira proferida para um público local - uma vez que os textos de viagem em geral se destinavam ao conhecimento do estrangeiro acerca do Brasil. Dela, portanto, se pode depreender seja uma estética da recepção, seja uma tentativa, sempre didática, de fomentar um ponto de intersecção entre Brasil e Portugal, efetivando, mesmo que com a efemeridade da palavra, uma intimidade poucas vezes experimentada nessa família lusófona. Ao som de um português híbrido e universalista como o de Vieira, que viveu em ambos os hemisférios, talvez a corte de d. João VI também aspirasse dar um novo tom à monarquia, mas longe de caracterizar-se como um fado a ser carregado, as memórias serviam de bóia para que o Quinto Império seguisse pairando sobre o oceano. 


\section{Referências}

\section{Fontes:}

BURMEISTER, Dr. Herman. Viagem ao Brasil através das províncias do Rio de Janeiro e Minas Gerais. Trad. Manuel Salvaterra e Hubert Schoenfeldt, Not. Augusto Meyer. São Paulo: Martins, 197?.

CAIRU, José da Silva Lisboa. Visconde. Memória dos beneficios políticos do governo de el rei Nosso Senhor Dom João VI. Rio de Janeiro: Imprensa Régia, 1818.

DEBRET, Jean Baptiste. Viagem pitoresca e histórica ao Brasil. São Paulo: Martins/ Brasília: INL, 1975. Trad. Sergio Miliet, notas Rubens Borba de Moraes. Vol I e II, tomo I.

DENIS, Ferdinand. Brasil. Pref. Mário Guimarães Ferri. Trad. João Etienne Filho e Matta Lima. Belo Horizonte: Itatiaia/ São Paulo: USP, 1980.

EBEL, Ernest. O Rio de Janeiro e seus arredores em 1824. São Paulo: Brasiliense, 1972. (trad. e anot. Joaquim de Souza Leão Filho).

EWBANK, Thomas. Vida no Brasil ou diário de uma visita à terra do cacaueiro e da Palmeira. São Paulo: Itatiaia, 1976.

FÉNELON, François. Diálogos sobre a eloquência. Lisboa: Oficina de António Rodrigues Galhardo, 1761.

FORTES, Pe. Inácio Felizardo. Breve exame de pregadores, pelo que pertence a arte de Retórica, extraído da Obra intitulada: $O$ pregador instruído nas qualidades necessárias para bem exercer $o$ seu ministério; pelo (...).(Publicações da Imprensa Régia, M.C.C. 1818).

GARDNER, George. Viagem ao interior do Brasil: principalmente nas províncias do norte e nos distritos do ouro e diamante, durante os anos de 1836-1841. São Paulo: Itatiaia, 1975.

IHGB, Almanaque do Rio de Janeiro para o ano de 1816. Revista do Instituto Histórico e Geográfico Brasileiro, vol. 268, jul-set/ 1965, Rio de Janeiro.

IHGB, Almanaque do Rio de Janeiro para o ano de 1824. Revista do Instituto Histórico e Geográfico Brasileiro, vol. 278, jan-mar/ 1968, Rio de Janeiro.

LOBÃO, Manoel D’Almeida e Souza de. Tratado prático compendiário dos censos, conforme a nossa legislação, costumes deste reino e das nações em que a Bulla de Pio V não foi recebida e conforme as mais sólidas e depuradas opiniões dos DD. Lisboa: Imprensa Régia, 1815. 
LUCCOCK, John. Notas sobre o Rio de Janeiro e partes meridionais do Brasil. Tomadas durante uma estada de 10 anos nesse país (de 1808 a 1818). Trad. Milton da Silva Rodrigues. São Paulo: Martins, 197 ?

MACEDO, J. M. de. Um Passeio pela cidade do Rio de Janeiro. Rio de Janeiro: Planeta do Brasil, 2004, vol. I.

MAWE, John. Viagens ao interior do Brasil. Pref. Mário G. Ferri. Trad. e Not. Clado Ribeiro Lessa e Selena B. Viana. São Paulo: Itatiaia/ Edusp, 1978.

MENDES de ALMEIDA, Dr. Candido. Atlas do Império do Brasil. (Notícia literária por F.I.M. Homem de Mello). Rio de Janeiro: Typographia de Quirino \& Irmão, 1869.

MONTE ALVERNE, Francisco do. Obras Oratórias. Rio de Janeiro: Garnier, 1858.

NOSSA SENHORA, Frei Bento de. Elementos da arte oratória ou os princípios da retórica portuguesa, em que se expõe com toda a clareza as regras mais principais della, exemplificadas com as melhores passagens, assim dos Poetas Latinos e Portugueses, como dos mais célebres Oradores da França e de Portugal. Escrita Para o uso de todo o género de pessoas, que ignoram a lingua latina e principalmente para os que se querem dar ao Ministério da Divina Palavra, por Fr. Bento de Nossa senhora. Pregador jubilado e filho da Reformada e Real Província da Conceição no Reino de Portugal. Lisboa: Na Oficina de Simão Thaddeo Ferreira, 1792 (M.DCC.XCII)

PORTUGAL. Alvará pelo qual Vossa Alteza Real há por bem determinar, que nas Igrejas das Ordens do Brazil, e domínios ultramarinos, que daqui em diante se proverem, se imponha huma módica pensão para a Fabrica da sua Real Capella. Registrado na Secretaria de Estado dos Negócios do Brasil no Livro I de Leis, Alvarás e Cartas Régias a Fol. 50 X. Rio de Janeiro: 20 de agosto de 1808.

RUGENDAS, João Maurício. Viagem Pitoresca através do Brasil. São Paulo: Livraria Martins., 1976.

SAINT-HILAIRE, Auguste. Viagem à Província de São Paulo e resumo das viagens ao Brasil, Província da Cisplatina e Missões do Paraguai. Trad. e Pref. Rubens Borba de Moraes. São Paulo: Livraria Martins, 1903.

SÃO CARLOS, Frei Francisco de. Oração de aç̧ão de graças, recitada no dia 7 de Março de 1809 na capella real, dia anniversario da feliz chegada de sua Alteza Real a esta cidade... Rio de Janeiro: Na Impressão Regia, 1809.

SILVA, J.M. Pereira. Biografia dos Brasileiros distintos por armas, letras, virtudes, etc. Frei Francisco São Carlos. Revista do Instituto Histórico e Geográfico Brasileiro, tomo X, 2 ed., Garnier, 1870, Rio de Janeiro. 
SPIX, J. B. von. MARTIUS, C.F.P. von. Viagem pelo Brasil (1817 - 1820). Trad. Lúcia Lahmeyer, revis. Ramiz Galvão e Basílio de Magalhães. São Paulo: Melhoramentos, 19767.

VARNHAGEM. História da Independência do Brasil. SP: Melhoramentos, 1957. 3. ${ }^{a}$ ed. Revista e anotada por Hélio Viana (Barão do Rio Branco/IHGB).

WOLF, Ferdinand. O Brasil literário: história da literatura brasileira. São Paulo: Companhia Editora Nacional, 1955. Pref./Trad. Jamil Almansul Haddad Sirú. Vol. 278.

\section{Estudos}

AGUIAR, Miguel. Conde de $d$. Henrique. Biografias Vimaranenses, vol. 167. Ano? https://www.academia.edu/4862239/Conde D. Henrique

ANDERSON, Perry. Linhagens do Estado absolutista. São Paulo: Brasiliense, 1989.

ARGAN, Giulio. A História da cidade como história da arte. São Paulo: Martins Fontes, 2014.

BICALHO, Maria Fernanda. A cidade e o Império: o Rio de Janeiro no século XVII. Rio de Janeiro: Civilização Brasileira, 2003.

CAVALCANTI, Nireu. $O$ Rio de Janeiro setecentista: a vida e a construção da cidade da invação francesa até a chegada da corte. Rio de Janeiro: Zahar, 2004.

CARDIM, Pedro. Amor e amizade na cultura política dos séculos XVI e XVII. LUSITANIA SACRA, 2a série, 11 (1999). 21-57 pp.

CHOUAY, François. Alegoria do patrimônio. São Paulo: Edunesp, 2001.

DURAN, M. R. C.; DURAN, M.R.C. . La polisemia de la cultura y de la política en el patrimonio histórico en Brasil: del Rio de Janeiro ochocentista a los indios contemporâneos.. Baukara, v. 3, p. 99-122, 2013.

(el al.). Paul Ricoeur e o lugar da memória na historiografia contemporânea. Dimensões: Revista de História da UFES, v. 30, p. 213-244, 2013.

_. Retórica à moda brasileira: transições da cultura oral para a cultura escrita no ensino fluminense de 1746 a 1834. 1. ed. São Paulo: Editora Unesp, 2013. v. 1. 200p .

. Ecos do Púlpito. Oratória sagrada no Rio de Janeiro de d. João VI. 1. ed. São Paulo: Edunesp, 2010. v. 500. 206p . 
DURAN, M.R.C.; BRAGA, I.D. Educação sentimental na oratória sagrada portuguesa setecentista. São Carlos, EDUSFCAR, 2018 (no prelo).

FRANÇA, Jean Marcel Carvalho. Literatura e sociedade no Rio de Janeiro oitocentista. Lisboa: Casa da Moeda/ Imprensa Nacional, 1999.

HOLANDA, Sergio Buarque. Cadernos de literatura colonial. São Paulo, Brasiliense, 1991.

HESPANHA, Antonio Manuel. O caleidosco pio do Antigo Regime. Sa o Paulo: Alameda, 2010.

LEITE, Miriam L. Moreira. Livros de viagem (1803-1900). Rio de Janeiro: Editora UFRJ, 1997.

LENTZ, Thierry. Napoleão. Tradução C. Egrejas. São Paulo: Editora Unesp, 2008,

LUZ, Guilherme Amaral. Os jesuítas e a política da eloqüência na América portuguesa. In: SIMPÓSIO NACIONAL DE HISTÓRIA, 23., 2005, Londrina.

MARTINS, Wilson. História da inteligência brasileira (1794 - 1855). São Paulo: Cultrix, 1977.

MATOS, Luís Salgado de. O Estado de Ordens. Lisboa, ICS, 2004.

RENAULT, Delso. O Rio Antigo nos anúncios de jornais. Rio de Janeiro: José Olympio, 1969.

SÜSSEKIND, Flora. O Brasil não é longe daqui: o narrador, a viagem. São Paulo: Cia das Letras, 1990.

\section{Literatura}

CALVINO, Italo. Cidades Invisíveis. São Paulo, Companhia das Letras, 1990.

MANGUEL, Alberto. GUADALUPI, Gianni. Dicionário de lugares imaginários. Lisboa, Tinta da China, 2013.

Recebido em: 14-06-2017

Aceito em: 17-10-2017 